\begin{tabular}{rr} 
çağdaş & Yaratıcı Drama Dergisi 2015, 10(2), 223-234 \\
drama & www.yader.org \\
\hline
\end{tabular}

\title{
Which Drama? Creative or Theorical
}

\section{Onur Topaloğlu ${ }^{1}$}

\begin{tabular}{|c|c|}
\hline Makale Bilgisi & Öz \\
\hline DOI: $10.21612 /$ yader.2015.019 & Educational drama prioritizes the participation of students to education process, \\
\hline $\begin{array}{l}\text { Anahtar Sözcükler } \\
\text { Educational drama } \\
\text { Theory } \\
\text { Creative }\end{array}$ & $\begin{array}{l}\text { and increasing the feelings of empathy and tolerance during this process and the } \\
\text { way of creating original educational environments in line with the contributions of } \\
\text { each learner. For this reason, the flourish of constructivist educational philosophy } \\
\text { increased the advocators and practitioners of drama in education. In this manner, } \\
\text { this study searches for answer to the question of whether this course is dealt with its } \\
\text { own creative functions or regarded as any theoretical course referring the drama as } \\
\text { an art form. To this end, the researcher designed a Likert type questionnaire serving } \\
\text { to measure the students'inclination towards drama as a creative or an artistic form. } \\
\text { Following the validity and reliability stages of the instrument, it was administered } \\
\text { to } 65 \text { students in the department of ELT. All the subjects were attending the drama } \\
\text { course given to them in } 2014-2015 \text { academic year in fall term. Next, descriptive } \\
\text { statistical measurements in SPSS programme were conducted to analyse the related } \\
\text { data. These statistical procedure was assured with qualitative data gathered } \\
\text { through interviewing some of these students. The results of the study uncovered that } \\
\text { the related course was given to students in the form of any pure theatrical course } \\
\text { aiming to inform students about the birth and development of theatre by ignoring the } \\
\text { recommendations of Higher Board of Education. }\end{array}$ \\
\hline
\end{tabular}

\section{Hangi Drama? Yaratıcı ya da Kuramsal}

\begin{tabular}{l} 
Article Info \\
\hline DOI: $10.21612 /$ yader.2015.019 \\
\hline Keywords \\
Eğitimde drama \\
Teori \\
Yaratıcllk
\end{tabular}

1 Department of Teaching Foreign Languages, Faculty of Education, Ataturk University, E- mail: onur.topaloglu@atauni.edu.tr

\begin{abstract}
Ĕ̈itimde dramanın öncelikleri ĕgitim sürecine öğrencilerin katılması ve bu süreç içerisinde ögrencilerin hoşgörü ve diğerkâmlık duygularının artırılması ve öğrenme sürecinde bulunan her bireyin katkılarılla özgün eğitim atmosferlerine giden yolların yaratılmasıdır. Bu nedenle, yapılandırmacı eğitim anlayışının gelişmesi eğitimde dramanın uygulayıcılarını ve savunucularını artırmıştır. Bu araştırma, drama derslerinin kendi yaratıcı işlevleriyle mi ilgili yoksa teorik bir ders ve bir sanat formu olarak dramanın tiyatroyla mi ilgili olup olmadı̆̆ sorusuna cevap bulmaya çalışmaktadır. Araştırmacı tarafindan, öğrencilerin dramaya olan eğilimlerin bir sanat formu olarak mı yoksa yaratıcı drama olarak mı olduğu ölçmek için Likert tipi bir ölçme aracı tasarlanmıştır. Ölçme aracının geçerlilik ve güvenilirlik aşamaların takiben ölçek, İngiliz Dili Ĕgitimi anabilim dalından 65 ögrenciye uygulanmıştır. Araştırmadaki bütün katılımcılar 2014-2015 eğitim öğretim yılının güz döneminde verilen drama dersine katılmışlardır. Daha sonra araştırma verileri SPSS programında bağıml örneklem t-testi ile analiz edilmiş ve drama derslerine katılan ögrencilerden beş tanesiyle yarı yapılandırılmış görüşmeler gerçekleştirilmiştir. Araştırma sonuçları, ögrencilere verilen drama derslerinin Yüksek Öğretim Kurulu'nun önerilerinin aksine ögrencilere tiyatronun doğuşu ve gelişimiyle ilgili bilgi vermeyi amaçlayan tiyatroya ait bir ders biçimi olarak algılandı̆̆ını ortaya çıkarmıştır.
\end{abstract}




\section{Introduction}

The history of educational drama goes at least one hundred years back in England (Wagner, 1998). Harriet Finlay Johnson, as an English teacher, paved the significant steps in using the drama as an instructional method especially in the field of English language teaching (Adigüzel, 2013). Drama has also broadened its area of utilization in education with the contributions of John Dewey's views transforming the educational philosophy of those days. Afterwards, the researchers such as Henry Caldwell Cook, Peter Slade, and Brian Way contributed considerably to related field with their studies. However, the views and practices of Dorothy Heathcote has become one of the most important means for integrating drama to educational studies, therefore more people and countries began to show interest in drama in education (Sağlam, 2003). In this manner, Australia and New Zealand tried to give required importance to drama in education following the leadership of England and USA. However, these studies did not find the deserved interest in Turkey till the last decade of twentieth century. Although some leading studies attempted to be realised at the end of the Ottoman Empire, desired results were not reached. The foundation of the Republic in Turkey and the reforms made in the education system facilitated the necessity of integrating drama into educational system, and thus modern education plan tried to give due place to drama in the education (Adigüzel, 2013). Moreover, the researchers such as Selahattin Çoruh and Emin Özdemir contributed much to the improvement of drama in educational studies in the context of Turkey with the second half of twentieth century (San, 2006).

On the other hand, the inevitability of using drama in educational studies was realised in line with the changing conditions of world. Therefore, drama has been accepted as an educational method in creating the individuals questioning the nature of events. Moreover, the process of replacing teacher centred education system with the learner centred one increased the interest in drama and its usage in education. For this reason, both the Ministry of National Education and the Higher Education Council included the course of drama to related curriculums (Adigüzel, 2013). However, this positive action did not reverse the events in a short period, yet it is certain that drama established its own place in educational field. This may also be observed by means of the increase in scientific studies conducted on drama and education relationship.

As to the conducted studies on educational drama and incorporating into curriculum, Anderson \& Donelan (2009) try to draw attention to educational drama courses, and they also stated that these courses are gaining more importance in Australia and it is also supported financially by the government. In addition, it is emphasized that drama in education takes part in the related curriculums in some regions of Australia and it is practiced professionally. However, this study does not discuss beyond the historical development of drama in education in Australian context and the general attitude towards these courses.

On the other hand, O’Toole, Stinson, \& Moore (2009) produced a special book dealing with the historical struggle between curriculum and drama in England and Australia. They remark that although drama was not taken into consideration till 1960s, it began to find place in educational area with the development of communicative language teaching method. However, the struggle between curriculum and drama did not let drama taking place in the curriculum. This study specifically focuses on the function of drama as an art form or as an educational method used by the instructors. It is also indicated that drama is incorporated into the curriculum with its literary, educational and 
social-psychological features.

Pitfield (2011) carried out her study in the context of the course of educational drama incorporated into the English curriculum in 1989, and the views of students and teachers of English about the mentioned situation. This study asserts the requirement of classifying drama as an art form and an educational method. The teachers of drama, participating the study, claimed that the educational drama courses executed by English teachers are disrespectful against the nature of drama. However, English teachers indicated that while using drama in their lessons the focus of the course is heavily established on the artistic role of drama rather than its educational feature. Consequently, this study contributes to the related literature by putting emphasis on the necessity of providing balance between drama and English. This balance may be established by prompting English teachers to attend educational drama seminars and stay focused on language teaching principles during lessons. However, this study has actually been conducted on the relationship between drama and English as the first language, its contribution to second language literature would be limited.

When looking at the studies done in different disciplines in Turkey, the number of the studies is not low. Yet, it is certain that we are still behind Europe and English speaking countries such as USA and Australia. The basic reason for such a situation is the powerful dramatic tradition located in England; Australia and USA to whom transferred from England.

It is significant that the number of studies, done in graduate level regarding the relationship between drama and English language teaching, is very low. For example, Kara (2009) searched for the usage of drama in both National Education Institute and Higher Education. The sample has been determined as the students of undergraduate students, attended the drama courses before, of English Language and Teaching and German Language and Teaching departments in one of the Turkish universities. Moreover, a number of teachers are selected as sample representing the National Educational Institute. The result is interesting: While the Institute of National Education pays the required attention to drama courses and gives the sufficient hours of lessons to educational drama, the situation is the vice versa in the related university. In addition, the researcher specifies some troubles in the practice of drama courses in the university context.

On the other hand, the studies conducted in the other fields regarding educational drama give some hints related to the views of students and instructors with regard to the efficiency of drama courses. In this sense, Çetingöz (2012) indicated that the self-efficacy of the students in the department of pre-school education is sufficient towards using drama as an educational method. However, this self-efficacy seems changes through the classes and the gender as a result of the interviews done with the students and instructors of educational drama courses. Through reaching these results, the researcher planned her study in correlational and case study designs by using both quantitative and qualitative designs. She applied a questionnaire regarding the influence of creative drama on self- efficacy for students, and she then interviewed some of these students.

In one another study, Tarman and Kuran (2011) conducted their study based on the views and attitudes of students regarding the drama courses in the department of Social Sciences Teaching. They also conducted their study in mixed type of design through gathering both quantitative and qualitative data. For this reason, they prepared questionnaire and interview questions concerning the creative drama. All of the students attended drama courses before. The study revealed that many of the students indicated the efficiency of drama courses in the contributions of drama courses to both 
their career and personal development.

Kırmizi and Akkaya (2009) intends to draw attention to the difficulties encountered in the undergraduate curriculum of Turkish Teaching departments. The important result of this study regarding our research is the positive views of students and instructors towards drama in education courses. However, they also stated that these courses are not wholly integrated into the curriculum due to some problems of technical and practical such as the inadequacy of instructors in drama pedagogy and the lack of special drama classes.

To sum up, it has been determined that although there are some studies regarding the evaluation of drama in education courses in some other fields apart from English Language and Teaching departments, there is not similar studies done in English departments. This is an important issue for both the efficiency and improvement of drama courses in this field. In addition, the prior studies mostly dealt with the relationship between drama and self-efficacy, speaking skills, motivation and vocabulary teaching, thus evaluating drama courses regarding their practicability has not been investigated. For this reason, this study will investigate how the course of drama is approached in the department of English Language and Teaching in the context of Ataturk University.

\section{Purpose of the Study}

This study aims to investigate how the educational drama course is conducted in the department of ELT. In this regard, this study will deal with whether this course is carried out in line with the principles of creative drama or theoretical drama. While creative drama has been recommended by the Higher Board of Education of Turkey, theoretical drama may find place in departments regarding this course. For this reason, the research questions are as follow:

1. What are the views of students towards the course of drama in education concerning whether it is creative or theoretical?

2. Would the course achieve the objectives of drama in education courses determined by Higher Board of Education of Turkey?

\section{Limitations}

This study was conducted in Atatürk University, the department of English Language Teaching. In this manner, the results of this study is limited to the students of ELT department and the ones having taken educational drama course in Atatürk University.

\section{Method}

\section{Research Method}

This study has been designed in the descriptive research methodology because the very aim is to put forth the current situation of drama course in line with the views of students. The goal of descriptive studies is to generate basic knowledge regarding any topic or present the current status in a simple way (Mcmillan \& Schumacher, 2014). To this end, a questionnaire was designed by the researcher to detect the views of students concerning the content of drama course. 


\section{Sample}

The subjects of this study involves the undergraduate students enrolled in ELT department of Atatürk University. Moreover, the subjects were chosen from the ones taking the course of educational drama. There were totally 65 students contributing the study, and 51 of these students were female while 11 were male. Their ages changed between 20 and 30, and most of them were younger than 25 .

\section{Instruments}

The researcher designed a questionnaire titled as "Drama Course Awareness Questionnaire" to measure the views of students. This instrument involved 30 items following the process of factor analysis and reliability test. The questionnaire was conducted in Likert type scale and the answers were grouped as "strongly agree (5), agree (4), neutral (3), disagree (2) and strongly disagree (1)". The items of the instrument were generated through reviewing the related literature, and then the researcher took the suggestions of experts regarding the construct validity of questionnaire. Following the required changes done by explorer, the questionnaire were administered to students to determine the validity of measurement device. In this regard, four of the items were excluded from the instrument as they had some factor value less than .50. In addition, the Cronbach Alpha reliability value was measured as .089 showing a reliable conclusion (Field, 2009). On the other hand, to analyse the statistical results, SPSS program was used by the researcher. Descriptive statistics were mainly administered to analyse the data.

\section{Findings}

The results were analysed conducting descriptive statistical measurements. By doing so, the means of theoretical and creative items were calculated and the means of each item were obtained. According to descriptive statistics, the means showed that there is a significant difference between theoretical drama and creative drama results regarding the views of students. This also referred that students had knowledge about theoretical drama more than creative one. Moreover, the most significant items were as follow: The first item regarding the theoretical drama is "The plays related to English literature are dealt with in drama course." The 38.5 percent of the subjects rated "agree" choice and 35.4 percent drew strongly agree choice. Totally it becomes a positive answer of 73.9 regarding this item. In addition, the next item serves to measure the creative drama: the course of drama involves creating activities based on the personal experiences of participants. This item gives indicating information concerning students' lack of knowledge of creative drama because 63.1 percent responded as strongly disagree and disagree, and if we add the neutral answers the ratio increases to 86.2. What is more, one more item referring to creative drama is; "the course of drama prioritizes the activities created through improvisation". The result shows that 90.1 percent of the participants preferred strongly disagree, disagree and neutral choices. The item "the evaluation is done through written examination in drama course" obtained 75.4 percent of strongly agree and agree choices. Additionally, the subjects responded the item of "drama course gives information about the types of character" totally 86.2 percent of agree and strongly agree responses. The last item to be dealt with is "a drama play includes exposition, rising action, climax, and falling action and resolution sections". This item was rated agree and strongly agree by 93.9 percent of the subjects. 
Table 1. Means and Standard Deviations

\begin{tabular}{llll}
\hline & Mean & N & Std. Deviation \\
\hline Theoretical & 3.8298 & 65 & .54794 \\
Creative & 2.6978 & 65 & .70652 \\
\hline
\end{tabular}

On the other hand, qualitative data was also gathered by means of conducting semi-structured interviews with some of the students. The analysis of qualitative data assured the quantitative data results by indicating the theoretical way of this course. One of the students uttered following concerning this situation:

The course was mostly utilized through lecturing. We learned about the birth and development of drama and its types. We also got information about some prominent playwright and their plays.

In addition, learners stated that the course was mostly controlled by lecturer, and they only had participated course by means of little discussion sessions.

I could not participate to course apart from asking some questions.

Sometimes, lecturer was asking questions and waiting for answers. I wish we had participated explicitly.

However, the interesting point is some one of the students stated that she used drama in one of her presentation, and she liked it much. Yet, she performed this presentation not in drama course but any other one. In addition, some students uttered the efficiency of drama in incorporating learners to learning process as a result of their some little experiences. Whereas, they did not have any chance furthering this feeling and experience in the course of drama.

\section{Discussion}

The Higher Board of Education in Turkey included educational courses into the curriculum of ELT departments in 2007. However, this decision would bring itself some misunderstandings and misapplications because both the instructors and the students were unaware of educational drama. In this regard, our study aimed to uncover this case in the department of ELT. The results was not surprised because the students had more knowledge about theoretical drama compared to educational one. This somewhat refers that the related course was carried out in theoretical dramatic tradition. Indeed, this situation is more or less similar in the other departments of education faculties when looking at previous studies. Tutuman ve Demirtaş (2013) dealt with the drama performing procifiency of Turkish language teachers, and they concluded that there are some problems regarding the related point due to the lack of efficient drama courses in undergradute level. It is also stated that the more successful teachers in educational drama expressed that they participated the private courses or in-service training concerning drama, and this enhanced their knowledge towards drama. In this manner, undergradute education has little effect on the knowledge of teachers regarding drama. Additionally, in one another study conducted by Özkan, Şahbaz, \& Tüfekçioğlu (2011) concerning the views of students towards drama course given in Turkish Langauge Education departments. The results showed that althought students believe in the necessity and practicability of this course in 
their educational and social life, they state negative opinions regarding the content of the course, related materials and application. This case indicates that students would take this course without experiencing sufficient application but the theory was probably prioritised. Yazıc1 \& Demircioğlu (2013) carried out a similar study referring the department of pre-school education. They somewhat reached the similar results indicating the lack of proficiency regarding the instructor, the classes and the devices required for drama courses such as cushions. One more striking result is the necessity of instructors having theatrical and dramtical knowledge to be able to administer drama courses. What is more, Başç1 \& Gündoğdu (2011) also confirmed the positive aspects of drama in education such as bridging empathy among students, forcing them to participate the lesson and making themselves feel confident. However, all these behaviours may be gained in appropriate classes for drama education, and sufficient material required for the course. Although this study presents more positive results regarding the former ones, there are still similar problems regarding the applicaility of the lesson and the required physical conditions. To sum up, although the course of educational drama was added to the curriculum assuming it would be given as creative drama, the subjected students did not expose such kind of course.

\section{Conclusion}

Drama is used by the educationalists for more than one hundred years in Europe and America. This way of teaching does not only prompt students to participate the education process, but also enrichens the educational environment. In line with these goals, drama was added to the curriculum of the departments of education faculties and expected them to give this course regarding the conditions detemined by Higher Board of Education of Turkey. However, the studies done so far do reveal that there are some overlooked and misapplied things concerning the educational drama courses (Başçı \& Gündoğdu, 2011; Tarman \& Kuran, 2011; Kırmızı \& Akkaya, 2009; Tutuman \& Demirtaş 2013). These problems are ranked such as follow: Instructors' lack of knowledge towards creative drama; the insufficient physical conditions of universities such as lack of any special drama class; the lack of training programmes referring to drama such as in-service teachings. Taking all these insufficient conditions into consideration, it is clear that drama course is not paid attention as much as it requires. It is rather considered as any theoretical course requiring only books and classes. However, the reality says that professional training is required to give this course and the more is it is nature requring creative and fresh ideas and actions stemming from the teacher and learners.

\section{References}

Adıgüzel, Ö. (2013). Eğitimde yaratıcı drama. Ankara: Pegem.

Aldağ, E. (2010). The effects of creative drama on enhancement of motivation in language learning. Yayımlanmamış yüksek lisans tezi, Atatürk Üniversitesi, Erzurum.

Anderson, M., \& Donelan, K. (2009). Drama in schools: meeting the research challenges of the twenty-first century . Research in Drama Education: The Journal of Applied Theatre and Performance, 165-171.

Başçı, Z., \& Gündoğdu, K. (2011). Öğretmen adaylarının drama dersine ilişkin tutumları ve görüşleri: Atatürk Üniversitesi örneği. İlkögretim Online, 454-467.

Belhan, E. D. (2014). The use of drama activities to increase student motivation towards speaking English. Yayımlanmamış yüksek lisans tezi, Çağ Üniversitesi, Mersin. 
Bergil, A. S. (2010). Ingilizce öğretiminde konuşma becerilerini geliştirmeye yönelik alternatif bir teknik: yaratıcı drama. Yayımlanmamış yüksek lisans tezi, Gazi Osman Paşa Üniversitesi Sosyal Bilimler Enstitüsü, Tokat.

Brown, H. D. (2007). Principles of language learning and teaching. New York: Perason Education.

Byram, M., \& Fleming, M. (1998). Language learning in intercultural perspective. Cambridge : Cambridge University Press.

Çelen, İ. (2008). Eğitimde dramada uzaman rolü yaklaşımı ve İngilizce öğretimi: İlköğretim Dördüncü Sinıf Ögrrencileri Üzerine Bir Araştırma. Yayımlanmamış yüksek lisans tezi, Adnan Menderes Üniversitesi Sosyal Bilimler Enstitüsü, Aydın.

Çetingöz, D. (2012). Okul öncesi eğitimi öğretmen adaylarının yaratıcı drama yöntemini kullanmaya yönelik özyeterlilikleri. Hacettepe Üniversitesi Eğitim Fakültesi Dergisi, 131-142.

Creswell, J. W. (2009). Research design: qualitative, quantitative and mixed methods approaches. California: Sage.

Fleming, M. (2006). Justifying the atrs: drama and intercultural education. The Journal of Aesthetic Education, 54-64.

Gass, S. M., \& Selinker, L. (2008). Second language acquisition an introductory course. New York: Routledge.

Heathcote, G. B. (1999). So you want to use role play? A new approach in how to plan. Staffordshire: Trentham Books.

Kadan, Ö. F. (2013). Yaratıcı drama yönteminin ortaokul 7. sinıf öğrencilerinin İngilizce dersindeki başarı, tutum ve motivasyonlarına etkisi. Yayımlanmamış yüksek lisans tezi, Mustafa Kemal Üniversitesi Sosyal Bilimler Enstitüsü, Hatay.

Kao, S.-M., \& O'Neill, C. (1998). Words into worlds: learning a second language through process drama. London : Ablex Publishing Corporation.

Kara, Z. (2009). Yabancı dil eğitiminde eğitici drama oyunları ve teknikleri uygulamaya yönelik bir araştır$m a$. Yayımlanmamış yüksek lisans tezi, Çanakkale Onsekiz Mart Üniversitesi Sosyal Bilimler Enstitüsü, Çanakkale.

Kaya, N. B. (2010). Examination on self-efficacy of the pre-service taechers of classroom teacher and the pre-school teacher according to creative drama method. (pp. 4533-4539). İstanbul: Science Direct.

Kılıç, Ş. (2009). Yaratıcı dramanın İngilizce konuşmaya ve tutuma etkisi. Bolu Abant İzzet Baysal Üniversitesi.

Kırmızı, F. S., \& Akkaya, N. (2009). Türkçe öğretimi programında yaşanan sorunlara ilişkin öğretmen görüşleri. Pamukkale Üniversitesi Eğitim Fakültesi Dergisi , 42-54.

Mcmillan, J. H., \& Schumacher, S. (2014). Research in education: evidence based inquiry. Essex: Pearson.

O'Toole, J., Stinson, M., \& Moore, T. (2009). Drama and curriculum a giant at the door. Australia: Springer.

Özen, Z. (2011). Dorothy Heathcote'un yaratıcı drama yaklaşımları.. Ankara: Ankara Üniversitesi.

Özkan, B., Şahbaz, N. K., \& Tüfekçioğlu, B. (2011). Türkçe öğretmeni adaylarının tiyatro ve drama uygulamaları dersine yönelik görüşleri üzerine bir araştırma. Education Sciences, 2436-2445.

Pitfield, M. (2011). Re-constructing the relationship between drama and English: Student-teachers' perspectives at the end of an initial teacher education year. English in Education, 52-71.

Sağlam, T. (2003). Dramatik eğitim: amaç mı? araç mı? . Tiyatro Araştırmaları Dergisi, 4-21.

Sağlamel, H. (2009). An experimental study on the role of creative drama in alleviating language anxiety in speaking classes with reference to teachers' and learners' perceptions of language anxiety. Trabzon: Yayımlanmamış yüksek lisans tezi, Karadeniz Teknik Üniversitesi Sosyal Bilimler Enstitüsü, Trabzon.

San, İ. (2006). The development of drama in education in Turkey. Research in Drama Education: The Journal of Applied Theatre and Performance, 96-99.

Saraç, G. (2007). The use of creative drama in developing the speaking skills of young learners. Ankara: Yayımlanmamış yüksek lisans tezi, Gazi Üniversitesi Eğitim Bilimleri Enstitüsü, Ankara. 
Sipahi, B., Yurtkoru, E. S., \& Çinko, M. (2010). Sosyal bilimlerde Spss'le veri analizi. İstanbul: Beta Yayınc1lik.

Tarman, B., \& Kuran, B. (2011). Sosyal Bilgiler öğretmen adaylarının aldıkları drama dersinin mesleki ve kişisel gelişimlerine yönelik katkıları hakkında görüş ve tutumları. Selçuk Üniversitesi Ahmet Keleşoğlu Ĕgitim Fakültesi Dergisi, 85-110.

Terzier, C. (2012). The Use of creative drama as an instructional strategy to enhance vocabulary of 7 th and 8th grade sstudents in primary schools. Ankara Yayımlanmamış yüksek lisans tezi, Gazi Üniversitesi Eğitim Bilimleri Enstitüsü, Ankara.

Tutuman, O. Y., \& Demirtaş, V. Y. (2013). Türkçe öğretmenlerinin yaratıcı drama uygulama yeterlilikleri. Abant İzet Baysal Üniversitesi Ĕ̈itim Fakültesi Dergisi, 34-49.

Wagner, B. J. (1980). Dorothy Heathcote, drama as a learning medium. London: Hutchinson .

Wagner, B. J. (1998). Educational drama and language arts, what research shows. Porsmouth: Heinemann.

Yazıcı, T., \& Demircioğlu, Ö. (2013 ). Okul öncesi öğretmen adaylarının drama eğitimi yeterlilik düzeylerinin belirlenmesi. Dicle Üniversitesi Sosyal Bilimler Enstitüsü Dergisi , 115-141. 


\section{Appendix 1: The Awareness Questionnaire of Drama Course}

\section{Drama Dersi Farkındalık Anketi}

\section{Değerli Arkadaşlar,}

Bu anketin amacı almış ya da almakta olduğunuz drama dersinin içeriğine yönelik olarak, görüşleriniz hakkında bilgi edinmektir. Drama dersi içeriği göz önüne alınarak hazırlanmış olan maddelerin, aldığınız drama dersi doğrultusunda yanıtlanması çalışmamızın sağlıklı bir şekilde yürütülmesi açısından oldukça önemlidir. Anketi 1 (Kesinlikle Katılmıyorum) ile 5 ( Kesinlikle Katılıyorum) arası değişen değerlerden sizin için en uygun olanını işaretleyerek cevaplayabilirsiniz. Zaman ayırıp çalışmamıza katkı sağladığınız için teşekkür ederim.

Arş. Gör. Onur Topaloğlu onur.topaloglu@atauni.edu.tr

1. Cinsiyet ( ) Bay

( ) Bayan

2. Yaş

( ) $18-25$

( ) 26-30

( ) 30 ve üzeri

\begin{tabular}{|c|c|c|c|c|c|}
\hline & 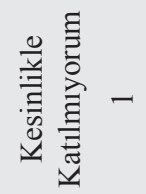 & 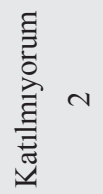 & 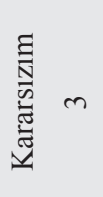 & 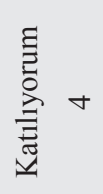 & 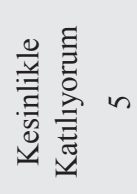 \\
\hline 1. Drama dersinde İngiliz edebiyatına ait oyunlar ele alınır. & & & & & \\
\hline $\begin{array}{l}\text { 2. Drama dersi, drama kavramlarının öğretilmesini } \\
\text { içermektedir. }\end{array}$ & & & & & \\
\hline $\begin{array}{l}\text { 3. Drama dersi öğrenenin merkezde olduğu, öğretmenin ise } \\
\text { rehberlik ettiği bir derstir. }\end{array}$ & & & & & \\
\hline $\begin{array}{l}\text { 4. Drama dersi, katılımcıların tecrübelerine dayalı etkinlikle } \\
\text { oluşturulmasını içermektedir. }\end{array}$ & & & & & \\
\hline $\begin{array}{l}\text { 5. Drama dersi rol yapma, rol oynama ve doğaçlama terimle } \\
\text { arasındaki farkları öğretmektedir. }\end{array}$ & & & & & \\
\hline $\begin{array}{l}\text { 6. Drama dersi, doğaçlama ile oluşturulan etkinlikleri öne } \\
\text { çıkarmaktadır. }\end{array}$ & & & & & \\
\hline $\begin{array}{l}\text { 7. Drama dersi, bir oyunu analiz ederken, oyun yazarının } \\
\text { hayatının, ilgili dönemin ve edebiyat akımının göz önüne } \\
\text { alınması gerektiğini öğretmektedir. }\end{array}$ & & & & & \\
\hline $\begin{array}{l}\text { 8. Drama dersi, dramanın tarihsel gelişimi hakkında bilgi } \\
\text { vermektedir. }\end{array}$ & & & & & \\
\hline $\begin{array}{l}\text { 9. Drama dersi dramaya ilişkin edebi akımlar (örn. Klassizm } \\
\text { hakkında bilgi vermektedir. }\end{array}$ & & & & & \\
\hline $\begin{array}{l}\text { 10. Drama dersi, katılımcıların yaşantıları doğrultusunda } \\
\text { oluşturdukları roller yoluyla birbirlerini değerlendirmelerine } \\
\text { imkan vermektedir. }\end{array}$ & & & & & \\
\hline $\begin{array}{l}\text { 11.Drama dersinde değerlendirme yazılı sınav yolu ile } \\
\text { gerçekleştirilmektedir. }\end{array}$ & & & & & \\
\hline $\begin{array}{l}\text { 12. Drama dersine göre, drama taklide (mimesis) dayalı bir } \\
\text { etkinliktir. }\end{array}$ & & & & & \\
\hline
\end{tabular}


13.Drama dersine göre bir drama etkinliğinde seyirci yoktur, herkes katılımcidır.

14. Drama lider, katılımcılar, mekan ve konu bileşenlerinden oluşmaktadır.

15. Drama dersine göre, drama sanatsal bir etkinliktir.

16. Drama dersi eğitim metodolojisi yoluyla öğrencilere grup olma becerisini kazandırmaktadır.

17. Drama dersine göre, bir drama oyununun sahnelenmesi için sahneye gereksinim duyulmaktadir.

18. Drama dersine göre, bir drama etkinliği mekan gözetmeksizin her yerde sahnelenebilmektedir.

19. Drama dersine göre, drama etkinliklerine katılmak herhangi oyunculuk yeteneği gerektirmez.

20. Drama dersi ele alınan metinler yoluyla eleştirel düşünmeyi kazandırmaktadır.

21. Drama dersi her katılımcıyı eşit görerek, demokratik bir öğrenme ortamı sağlamaktadır.

22. Drama dersi öğrenciye sesini ve vücudunu iletişimde daha etkili kullanması hususunda katkı sağlamaktadır.

23. Drama dersi, öğrencilerin Shakespeare ve Marlowe ... gibi edebi kişilikleri tanımasını sağlamaktadır.

24. Drama dersinde dramatik metinler yoluyla öğrenciler edebi ifadelere aşina olmaktadır.

25. Drama dersi, öğrencilerin farklı rolleri deneyimleyerek empati becerilerini geliştirmelerine katıkıda bulunmaktadır.

26. Drama dersi, karakter çeşitleri (protagonist, antagonist ve foil karakter) hakkında bilgi vermektedir.

27. Drama dersi, bir komedyanın (komik oyunun) sıradan insanların deneyimlerini ele aldığını ögretmektedir.

28. Drama dersi, trajik bir oyunun üst sınıftan bir bireyin düşüşünü konu aldığını öğretmektedir.

29. Drama dersi, bir drama etkinliğinin ısınma, canlandırma ve değerlendirme aşamalarından oluştuğunu öğretmektedir.

30. Drama dersine göre, bir drama oyunu exposition, rising action, climax, falling action ve resolution (denouement) bölümlerinden oluşmaktadır. 
